\title{
PENGARUH GAWAI DALAM POLA ASUH ORANG TUA TERHADAP ANAK USIA DINI \\ (Studi Kasus Orang Tua dari Anak Usia 5 Tahun di TKIT Ibu Harapan Kecamatan Bengkalis)
}

\author{
Mufaro'ah \\ STAIN Bengkalis \\ Email: muf.rohah@gmail.com \\ Titin Sumarni \\ STAIN Bengkalis \\ Email: titinijal@gmail.com \\ Ika Kurnia Sofiani \\ STAIN Bengkalis \\ Email: ikur.wafie@gmail.com
}

\begin{abstract}
Abstrak
This study aims to determine the effect of failure in parenting for early childhood and factors that inhibit or support parents in parenting. This research is a correlation study with product moment correlation analysis. The method in this study is to use a case study approach, instruments or tools used to obtain data through the dissemination and filling of questionnaires by parents, direct interviews with parents and documentation as secondary data so that the data obtained is more complete. After going through a fairly long process of data collection, processing and analysis, it can be seen that there are significant effects of gadgets in parenting for early childhood. The presentation was permissive parenting $88.31 \%$, democratic parenting $61.65 \%$ and authoritarian parenting $50.04 \%$. With the analysis that the three parenting styles above are influenced by gatget in the process of parenting parents to early childhood but the most strongly influenced are parents with permissive parenting. The factors that hinder parenting are many 5-year-olds who use gadgets, 5-year-olds can already be friends and choose friends, 5-year-olds have their own desires, and global technological developments. The factors that hinder parents in parenting are many 5-year-olds who use gadgets, 5-year-olds can play with friends and choose friends, 5-year-olds have their own desires, and increasingly sophisticated technology. Supporting factors for parents in parenting are good cooperation in the family, having the same commitment, consistency in caring for children, parents providing educational tools in accordance with the age of the child, and parents providing time to play with children. The solutions for parents, children and early childhood education institutions in caring for children should not be affected by gadgets. For parents, it is better to do and multiply positive activities.
\end{abstract}


Al-Ishlah: Jurnal Pendidikan - ISSN: 2087-949o (p); 2597-940X (e)

Vol. 11, No. 1 (2019)

Penelitian ini bertujuan untuk mengetahui pengaruh gawai dalam pola asuh orang tua terhadap anak usia dini dan faktor yang menghambat maupun mendukung orang tua dalam pengasuhan. Penelitian ini merupakan penelitian dengan analisis korelasi produk moment. Metode dalam penelitian ini dilakukan melalui pendekatan kuantitatif dengan korelasi produk moment dengan menggunakan pendekatan studi kasus. Instrumen atau alat yang digunakan untuk memperoleh data dilakukan melalui penyebaran serta pengisian angket oleh orang tua, wawancara langsung dengan orang tua, dan dokumentasi sebagai data sekunder agar data yang diperoleh lebih lengkap. Setelah proses pengumpulan, pengolahan, serta analisis data, dapat diketahui bahwa terdapat pengaruh yang signifikan pada pengaruh gawai dalam pola asuh orang tua terhadap anak usia dini. Adapun persentasenya adalah pola asuh permissif $88,31 \%$, pola asuh demokratis 61,65\%, dan pola asuh otoriter 50,04\%. Dengan analisis bahwa ketiga pola asuh tersebut dipengaruhi oleh gawai dalam proses pengasuhan orang tua terhadap anak usia dini, tetapi yang paling kuat dipengaruhi oleh pola asuh permissif dari orang tua. Adapun faktor yang menghambat orang tua dalam pola asuh adalah banyaknya anak usia 5 tahun yang menggunakan gawai, anak usia 5 tahun sudah bisa bermain bersama teman-teman dan memilih teman, anak usia 5 tahun sudah mempunyai keinginan sendiri, dan perkembangan teknologi yang semakin canggih. Faktor pendukung bagi orang tua dalam pola asuh adalah adanya kerja sama yang baik dalam keluarga, memiliki komitmen yang sama, konsistensi dalam mengasuh anak, orang tua yang menyediakan alat permainan edukatif sesuai dengan usia anak, serta orang tua yang menyediakan waktu untuk bermain bersama dengan anak. Adapun beberapa solusi bagi orang tua, anak, dan lembaga pendidikan anak uisa dini dalam mengasuh anak agar tidak terpengaruh oleh gawai Bagi orang tua sebaiknya melakukan dan memperbanyak kegiatan yang positif.

Kata Kunci: Gawai, Pola Asuh Orang Tua, Anak Usia Dini

\section{PENDAHULUAN}

Perilaku seseorang dalam menggunakan gawai memiliki dampak positif maupun negatif. Dampak positif dalam penggunaan gawai antara lain dapat memudahkan seseorang dalam mengasah kreativitas dan kecerdasan, seperti belajar mewarnai, belajar membaca, dan menulis huruf. Tersedianya berbagai aplikasi seperti ini tentunya memberikan dampak positif terhadap otak anak. Anakanak tidak memerlukan waktu dan tenaga yang lebih untuk membaca dan menulis di kertas, anak-anak juga akan lebih bersemangat untuk belajar karena aplikasi seperti ini dilengkapi dengan gambar-gambar yang menarik, selain itu kemampuan berimajinasi anak juga semakin terasah. Sementara, orang tua yang memiliki anak usia dini dapat terbantu dalampembimbingan dan pengasuhan anak-anak. Selain itu, wawasan orang tua dalam mengasuh dan mendidik anak-anak bertambah pula. 
Al-Ishlah: Jurnal Pendidikan - ISSN: 2087-949o (p); 2597-940X (e)

Vol. 11, No. 1 (2019)

Namun demikian, penggunaan gawai juga berdampak negatif bagi anak maupun orang tua. Dengan kemudahan mengakses berbagai media informasi dan teknologi, anak-anak menjadi malas bergerak dan beraktivitas. Mereka lebih memilih duduk diam di depan gawai dan menikmati dunia yang ada dalam gadget tersebut. Begitu juga dengan orang tua, karena saking asyiknya bermain gawai, mereka jadi kurang memperhatikan perkembangan anak-anak secara langsung. Bahkan, akibat yang lebih besar lagi adalah habisnya waktu di depan gawai membuat interaksi sosial anak maupun orang tua mengalami gangguan. Kecenderungan penggunaan gawai yang berlebihan dan tidak tepat akan menjadikan seseorang bersikap tidak peduli pada lingkungannya, baik dalam lingkungan keluarga maupun masyarakat. Ketidakpedulian seseorang akan keadaan di sekitarnya dapat menjadikannya dijauhi bahkan terasing di lingkungannya. (Wahyu Novita Sari, 2016).

Dalam Islam, terdapat sebuah metode parenting yang tepat utuk mendidik anak berdasarkan Alquran dan Hadis, yaitu mendidik anak ala "Ali bin Abi Thalib R.A.”. Ali bin Abi Thalib R.A. adalah seorang sahabat nabi (khulafaur rasyidin), sepupu, sekaligus menantu Rasulullah Sallallahu' Alaihi Wassalam (suami dari anaknya yang bernama Fatimah Az-Zahra). Kutipan yang terkenal dari Ali bin Abi Thalib RA adalah, "Didiklah anakmu sesuai dengan zamannya, karena mereka hidup bukan di zamanmu."

Pembinaan dan pengasuhan anak sebelum pendidikan dasar merupakan tanggung jawab penuh bagi orang tua untuk mengembangkan sikap menjunjung tinggi nilai luhur budaya bangsa, teladan, dan disiplin dalam masyarakat, bangsa, dan negara yang harus dilaksanakan sendiri dalam lingkungan keluarga, sekolah, dan masyarakat. Melalui pendidikan keluarga, komunikasi orang tua dengan anak sangatlah penting dalam rangka pembentukan sikap seorang anak. Komunikasi dalam keluarga diharapkan menjadi media interaksi agar dapat saling bertukar pengetahuan, pendapat, pengalaman, dan sebagainya.

Dari teori tersebut, ada beberapa gejala yang ditemukan di lapangan, yaitu: terdapatnya beberapa orang tua yang menggunakan gawai di rumah pada saat anaknya sedang belajar; terdapatnya beberapa orang tua yang memegang gawai pada saat anaknya bermain; terdapatnya beberapa orang tua yang memegang gawai pada saat menjelang anaknya tidur; terdapatnya beberapa orang tua yang berbicara dengan anaknya sambil memegang gawai; terdapatnya beberapa orang tua yang tidak menggunakan gawai untuk menambah wawasan dalam pengasuhan; terdapatnya beberapa orang tua yang membiarkan anaknya membawa gawai ke sekolah; terdapatnya beberapa orang tua yang membiarkan anaknya berlama-lama bermain gawai; terdapatnya beberapaorang tua yang menyelesaikan masalah anak dengan memberikan gawai; terdapatnya beberapa anak usia 5 tahun yang asyik dengan gawai daripada bermain dengan orang tuanya; terdapatnya beberapa anak 
Al-Ishlah: Jurnal Pendidikan - ISSN: 2087-949o (p); 2597-940X (e)

Vol. 11, No. 1 (2019)

yang asyik bermain gawai daripada bermain dengan teman-teman; terdapat beberapa anak yang membawa gawai ke sekolah; terdapatnya beberapa anak yang suka bermain game dari pada belajar; terdapatnya beberapa anak yang suka bermain Youtube. Bahkan, berdasarkan data dari lembaga perlindungan perempuan dan anak, ada beberapa anak usia dini yang menjadi korban maupun pelaku asusila akibat bermain gawai.

Gawai memiliki manfaat terhadap tumbuh kembang anak usia dini. Pertama, menambah pengetahuan anak usia dini. Pada gawai, terdapat banyak aplikasi edukatif yang tersedia untuk anak-anak yang dapat melatih proses perkembangan otak dan membantu proses pembelajaran anak usia dini. Dengan menggunakan gawai yang berteknologi canggih, anak-anak juga dapat mengakses fitur-fitur permainan yang dapat mendukung berbagai aspek tumbuh kembang mereka. Kedua, memperluas jaringan persahabatan anak usia dini. Melalui gawai anak usia dini dapat memperluas jaringan persahabatan mereka karena dapat dengan mudah dan cepat bergabung ke media sosial yang telah disediakan (Nurrachmawati, 2014).

Penggunaan gawai berdampak negatif pula terhadap perkembangan anak. Dengan adanya kemudahan dalam mengakses berbagai media informasi dan teknologi, menyebabkan anak-anak menjadi malas bergerak dan beraktivitas. Mereka lebih memilih duduk di depan gawai dan menikmati permainan yang ada pada fitur-fitur tertentu dibandingkan berinteraksi dengan dunia nyata. Hal ini tentu berdampak buruk bagi perkembangan dan kesehatan anak, terutama pada otak dan psikologis. Dampak negatif lain juga dapat menyebabkan kurangnya mobilitas sosial pada pada anak. Mereka lebih memilih bermain menggunakan gawai daripada bermain bersama teman sebaya.Tidak jarang terlihat anak mengalami kesulitan untuk berkonsentrasi karena otak anak sudah diforsir pada dunia yang tidak nyata (Ameliola \& Nugraha, 2013).

Pada hakikatnya, anak-anak belum saatnya mengenal gawai. Mereka masih memerlukan permainan-permainan yang dapat merangsang otak dan menunjang semua aspeknya, baik aspek fisik, kognitif, sosial-emosional, bahasa, dan moral. Orang tua perlu mendampingi dan membimbing anaknya saat sedang menggunakan gawai. Dalam hal ini, peran orang tua untuk mendisiplinkan sangat dibutuhkan agar anak tidak mengalami ketergantungan yang akan menyebabkan dampak negatif terhadap perkembangan anak (Ameliola \& Nugraha, 2013). Menurut Maulida (2013), tanda-tanda anak usia dini yang kecanduan gawai adalah sebagai berikut: (1) kehilangan keinginan untuk beraktivitas; (2) berbicara tentang teknologi secara terus menerus; (3) cenderung sering membantah suatu perintah jika itu menghalangi dirinya mengakses gawai; (4) sensitif atau gampang tersinggung, menyebabkan mood yang mudah berubah; (5) egois, sulit berbagi waktu dalam penggunaan gawai dengan orang lain; (6) 
Al-Ishlah: Jurnal Pendidikan - ISSN: 2087-949o (p); 2597-940X (e)

Vol. 11, No. 1 (2019)

sering berbohong karena sudah tidak bisa lepas dengan gawai, dengan kata lain, anak akan mencari cara apapun agar tetap bisa menggunakan gadget meskipun mengganggu waktu tidurnya.

Dari sudut pandang ilmu kesehatan jiwa, penggunaan gadget untuk usia dini sangat tidak disarankan karena dapat mengganggu proses tumbuh kembangnya secara alami. Terbatasnya kesempatan untuk belajar disebabkan dengangadget anak hanya berkomunikasi satu arah. Anak tidak dapat belajar secara alami cara berkomunikasi dan bersosialisasi. Anak juga tidak mampu mengenali dan berbagi aneka emosi, misalnya simpati, sedih, atau senang, sehingga anak tidak dapat merespons hal yang ada di sekelilingnya, baik secara emosional maupun verbal. Terbatasnya respons anak akan mengganggu perkembangan kemampuannya untuk bergaul dan beradaptasi.

Pola asuh orang tua adalah keseluruhan interaksi antara orang tua dengan anak, dengan stimulasi yang diberikan orang tuan terhadap anaknya untuk mengubah tingkah laku, pengetahuan, serta nilai-nilai yang dianggap paling tepat oleh orang tua, agar anak mandiri, tumbuh, dan berkembang secara sehat dan optimal. Pada pengelompokan pola asuh orang tua dalam mendidik anak, para ahli mengemukakan pendapat yang berbeda-beda antara satu sama lain, tetapi pada prinsipnya sama. Oleh karena itu, dari beberapa teori yang ada, penulis lebih cenderung menggunakan dasar teori Hurlock (1993, 37-41), sebagai landasan dalam membuat konsep operasional. Hurlock membedakan pola asuh menjadi tiga, yaitu sebagai berikut.

\section{1) Authoritative Parenting (Pola Asuh Demokratis)}

Authoritative parenting atau pola asuh demokratis adalah salah satu bentuk perlakuan yang dapat diterapkan orang tua dalam rangka membentuk kepribadian anak dengan cara memprioritaskan kepentingan anak yang bersikap rasional atau pemikiran-pemikiran. Pola asuh authoritative mempunyai ciri-ciri, yaitu: anak diberi kesempatan untuk mandiri dan mengembangkan kontrol internal; anak diakui sebagai pribadi oleh orang tua dan turut dilibatkan dalam pengambilan keputusan; dan menetapkan peraturan serta mengatur kehidupan anak. Orang tua menggunakan hukuman fisik yang diberikan jika terbukti anak secara sadar menolak melakukan apa yang telah disetujui bersama, sehingga lebih bersikap edukatif. Pola asuh authoritative memprioritaskan kepentingan anak, tetapi tidak ragu-ragu mengendalikan mereka. Orang tua dengan pola asuh ini bersikap rasional, selalu mendasari tindakannya pada rasio atau pemikiran- pemikiran. Orang tua tipe ini juga bersikap realistis terhadap kemampuan anak, tidak berharap berlebihan yang melampaui kemampuan anak, memberikan kebebasan kepada anak untuk memilih dan melakukan suatu tindakan, dan mendekati anak dengan hangat.

Pola asuh authoritative mempunyai karakteristik sebagai berikut; orang tua 
Al-Ishlah: Jurnal Pendidikan - ISSN: 2087-949o (p); 2597-940X (e)

Vol. 11, No. 1 (2019)

bersikap acceptance dan mengontrol tinggi, bersikap responsif terhadap kebutuhan anak, mendorong anak untuk menyatakan pendapat atau pertanyaan, memberikan penjelasan tentang dampak perbuatan yang baik dan buruk, bersikap realistis terhadap kemampuan anak, memberikan kebebasan kepada anak untuk memilih dan melakukan suatu tindakan, menjadikan dirinya sebagai model panutan bagi anak, hangat dan berupaya membimbing anak, melibatkan anak dalam membuat keputusan, berwenang untuk mengambil keputusan akhir dalam keluarga, dan menghargai disiplin anak.

Melalui pola asuh authoritative akan membentuk profil perilaku anak yang memiliki rasa percaya diri, bersikap bersahabat, mampu mengendalikan diri (selfcontrol), bersikap sopan, mau bekerja sama, memiliki rasa ingin tahu yang tinggi, mempunyai tujuan atau arah hidup yang jelas, dan berorientasi terhadap prestasi.

2) Authoritarian Parenting (Pola Asuh Otoriter)

Authoritarian parenting atau pola asuh otoriter adalah salah satu bentuk perlakuan yang diterapkan orang tua pada anak dalam rangka membentuk kepribadian anak dengan cara menetapkan standar mutlak harus dituruti, biasanya dibarengi dengan ancaman-ancaman. Pola asuh authoritarian mempunyai ciri-ciri, yaitu: anak harus tunduk dan patuh pada kehendak orang tua; pengontrolan orang tua pada tingkah laku anak sangat ketat; hampir tidak pernah memberi pujian; sering memberikan hukuman fisik jika terjadi kegagalan memenuhi standar yang telah ditetapkan orang tua. Pengendalian tingkah laku dilakukan melalui kontrol eksternal. Pola asuh ini cenderung menetapkan standar yang mutlak harus dituruti, biasanya dibarengi dengan ancaman-ancaman. Orang tua tipe ini cenderung memaksa, memerintah, dan menghukum. Apabila anak tidak mau melakukan apa yang dikatakan oleh orang tua, orang tua tipe ini tidak segan menghukum anak. Orang tua tipe ini juga tidak mengenal kompromi dan dalam komunikasi biasanya bersifat satu arah. Orang tua tipe ini tidak memerlukan umpan balik dari anaknya untuk mengerti mengenai anaknya.

Pola asuh authoritarian menerapkan pola asuh dengan indikator orang tua mengekang anak untuk bergaul dan memilih-milih orang yang menjadi teman anaknya, tidak memberikan kesempatan pada anaknya untuk berdialog, mengeluh, dan mengemukakan pendapat. Anak harus menuruti kehendak orang tua tanpa peduli keinginan dan kemampuan anak. Orang tua menentukan aturan bagi anak dalam berinteraksi, baik di rumah maupun di luar rumah. Aturan tersebut harus ditaati oleh anak walaupun tidak sesuai dengan keinginan anak, orang tua melarang anaknya untuk berpartisipasi dalam kegiatan kelompok, orang tua menuntut anaknya untuk bertanggung jawab terhadap tindakan yang dilakukannya, tetapi tidak menjelaskan kepada anak alasan anak harus bertanggung jawab. 
Al-Ishlah: Jurnal Pendidikan - ISSN: 2087-949o (p); 2597-940X (e)

Vol. 11, No. 1 (2019)

Dengan demikian, karakteristik pola asuh ini akan membentuk profil perilaku anak seperti: (a) mudah tersinggung, (b) penakut, (c) pemurung dan merasa tidak bahagia, (d) mudah terpengaruh, (e) mudah stres, (f) tidak mempunyai arah masa depan yang jelas, dan $(\mathrm{g})$ tidak bersahabat.

3) Permissive Parenting (Pola Asuh Permisif)

Permissive parenting atau pola asuh permisif adalah salah satu bentuk perlakuan yang dapat diterapkan orang tua pada anak dalam rangka membentuk kepribadian anak dengan cara memberikan pengawasan yang sangat longgar serta memberikan kesempatan pada anak untuk melakukan sesuatu tanpa pengawasan yang cukup darinya. Orang tua cenderung tidak menegur atau memperingatkan anak apabila anak sedang dalam bahaya dan sangat sedikit bimbingan yang diberikan oleh mereka. Namun, orang tua tipe ini biasanya bersifat hangat, sehingga seringkali disukai oleh anak.

Pola asuh permisif memiliki karakteistik sebagai berikut: (1) orang tua bersikap acceptance yang tinggi, tetapi kontrolnya rendah. Anak diizinkan membuat keputusan sendiri dan dapat berbuat sekehendaknya sendiri; (2) orang tua memberi kebebasan kepada anak untuk menyatakan dorongan atau keinginannya; dan (3) orang tua kurang menerapkan hukuman pada anak, hampir tidak menggunakan hukuman.

Pola asuh permisif menerapkan pola asuh dengan indikator sebagai berikut.

a. Orang tua tidak peduli terhadap pertemanan atau persahabatan anak.

b. Orang tua kurang memberikan perhatian terhadap kebutuhan anak. Jarang sekali terjadi dialog, terlebih untuk mengeluh dan meminta pertimbangan.

c. Orang tua tidak peduli terhadap pergaulan anaknya dan tidak pernah menentukan norma-norma yang harus diperhatikan dalam bertindak.

d. Orang tua tidak perduli dengan masalah yang dihadapi oleh anaknya.

e. Orang tua tidak peduli terhadap kegiatan kelompok yang diikuti anaknya.

f. Orang tua tidak peduli anaknya bertanggung jawab atau tidak atas tindakan yang dilakukannya.

Dengan demikian, karakteristik pola asuh ini akan membentuk profil perilaku anak seperti

1. bersikap impulsif dan agresif,

2. suka memberontak,

3. kurang memiliki rasa percaya diri dan pengendalian diri,

4. suka mendominasi,

5. tidak jelas arah hidupnya,

6. prestasinya rendah.

Dari beberapa teori di atas, penulis cenderung menggunakan teori Hurlock (Badingah, 1993) yang mengatakan bahwa pola asuh dibagi menjadi tiga, yaitu authoritative parenting (pola asuh demokratis), authoritarian parenting (pola 
Al-Ishlah: Jurnal Pendidikan - ISSN: 2087-949o (p); 2597-940X (e)

Vol. 11, No. 1 (2019)

asuh otoriter), dan permissive parenting (pola asuh permisif).

Faktor-faktor yang Mempengaruhi Pola Asuh adalah sebagai berikut.

a. Budaya

Orang tua mempertahankan konsep tradisional mengenai peran orang tua, bahwa orang tua berhasil mendidik mereka dengan baik, mereka menggunakan teknik yang serupa dalam mendidik anak mereka.

b. Pendidikan Orang tua

Orang tua yang memiliki pengetahuan lebih banyak dalam mengasuh anakakan mengerti kebutuhan anak.

c. Status Sosial Ekonomi

Orang tua dari kelas menengah rendah cenderung lebih keras/lebih permisif dalam mengasuh anak (Hurlock, E,B2002).

d. Perkembangan Teknologi

Kebutuhan teknologi merupakan salah satu kebutuhan penting saat ini karena teknologi dibutuhkan untuk banyak keperluan, apalagi saat ini didukung dengan munculnya teknologi melalui berbagai jenis dan fitur, salah satunya adalah gawai. Gawai saat ini sudah dipenuhi dengan fitur-fitur yang banyak membuat anak tertarik untuk bermain gawai, sehingga anak bisa berlama-lama bermain tanpa mengenal waktu jika tidak didampingi oleh orang tua.

e. Maraknya game pada aplikasi gawai membuat anak kecanduan untuk bermain .

f. Tidak tersedia paket belajar yang lengkap pada aplikasi gawai untuk menambah pengetahuan anak, seperti tidak ada aplikasi untuk belajar agama, tidak ada aplikasi paket belajar untuk anak.

g. Tidak ada kerja sama yang baik antara guru dan orang tua dalam pola pengasuhan anak.

h. Dari hasil wawancara dan pengamatan penulis, sebagian orang tua tidak mengetahui cara blocking site pada gawai seperti blocking site untuk Youtube.

Definisi anak usia dini menurut National Association For The Education Young Children (NAEYC) adalah bahwa anak usia dini atau "early childhood" merupakan anak yang berada pada usia $0-8$ tahun. Masa tersebut merupakan proses pertumbuhan dan perkembangan dalam berbagai aspek rentang kehidupan manusia. Penggunaan istilah anak usia dini dalam PAUD mengindikasikan kesadaran yang tinggi pada pihak pemerintah sebagai pemerhati pendidikan untuk menangani pendidikan anak-anak secara profesional dan serius. Penanganan anak usia dini, khusunya dalam bidang pendidikan, sangat menentukan kualitas pendidikan bangsa di masa mendatang. Pada masa usia dini, kualitas hidup seseorang memiliki makna dan pengaruh yang luar biasa untuk kehidupan selanjutnya. Oleh karena itu, pada masa perkembangan anak ketika masa "the golden age". 
Al-Ishlah: Jurnal Pendidikan - ISSN: 2087-949o (p); 2597-940X (e)

Vol. 11, No. 1 (2019)

Periode usia dini dalam pelajaran kehidupan manusia merupakan periode penting bagi pertumbuhan otak, intelegensi, kepribadian, memori, dan aspek perkembangan yang lainnya. Artinya, terhambatnya pertumbuhan dan perkembangan pada masa ini, dapat mengakibatkan terhambatnya pada masamasa selanjutnya Bredekamp (1992:6). Pengertian tentang prinsip perkembangan anak sangat penting untuk diketahui agar diperoleh gambaran secara umum perilaku anak pada tahap tertentu. Pengetahuan ini juga bermanfaat untuk memberikan bimbingan dan rangsangan tertentu agar anak dapat mencapai kemampuan sepenuhnya, serta memungkinkan guru mempersiapkan kematangan yang diharapkan dari anak-anak pada usia tertentu.

Berdasarkan hasil penelitian diketahui terdapat sepuluh fakta pada prinsip perkembangan selama masa anak-anak. Hal ini tidak menutup kemungkinan ditemukannya lagi prinsip-prinsip baru sejalan dengan berlanjutnya penelitian. Sepuluh prinsip yang dimakud seperti dikemukakan oleh Elizabath B. Hurlock (1997: 22-47), yang gambaran sebagai berikut.

1) Perkembangan yang menyangkut perubahan.

Tujuan perkembangan adalah aktualisasi diri atau pencapaian kemampuan seorang anak. Berbagai perubahan ini dipengaruhi oleh beberapa hal berikut.

a. Kesadaran anak akan perubahan.

b. Dampak perubahan terhadap perilaku anak.

c. Sikap sosial terhadap perubahan.

d. Sikap sosial sebagai akibat dari perubahan penampilan anak.

e. Sikap budaya yang merupakan cerminan dari orang memperlakukan anak sebagai akibat perubahan dan penampilan.

Perkembangan awal lebih penting dari pada perkembangan selanjutnya karena perkembangan awal sangat dipengaruhi oleh proses belajar dan pengalaman. Apabilah perkembangan lingkungan membahayakan terhadap pribadi dan sosial anak, ia dapat diubah sebelum menjadi pola kebiasaan. Lingkungan merupakan tempat anak berinteraksi dan tempat pembentukan awal kehidupannya, serta mempunyai pengaruh kuat terhadap kemampuan bawaan pada anak. Hal yang berpengaruh besar dalam hal ini adalah hubungan antarpribadi, keadaan emosi, pola pengasuhan, peran dalam keluarga, struktur keluarga pada masa kanak-kanak, dan rangsangan dari lingkungan.

Perkembangan merupakan hasil proses kematangan dan belajar. Ciri perkembangan, baik fisik maupun mental, sebagain besar dari proses kematangan intrinsik bergantung pada interaksi antara faktor-faktor bawaan dengan faktor sosial dan budaya lingkungan yang mempengaruhi.

Pola perkembangan dapat diprediksi karena memiliki pola tertentu. Studi genetik bayi sejak lahir hingga umur lima tahun telah menunjukkan bahwa semua anak kecil mengikuti pola perilaku umum yang relatif beraturan. Bidang spesifik 
Al-Ishlah: Jurnal Pendidikan - ISSN: 2087-949o (p); 2597-940X (e)

Vol. 11, No. 1 (2019)

perkembangan juga mengikuti pola yang dapat diprediksi. Ini mencakup berbagai aspek, yaitu perkembangan motorik, perilaku, emosional, bicara, perilaku sosial, perkembangan konsep, cita-cita, minat, dan identifikasi terhadap orang lain. Pola perkembangan tersebut dipengaruhi juga oleh kondisi lingkungan pada masa pralahir dan pascalahir.

2) Pola perkembangan mempunyai karakteristik penting yang dapat diprediksi.

Karakteristik yang perlu diperhatikan di antaranya sebagai berikut.

a. Adanya persamaan pola perkembangan bagi semua anak.

b. Perkembangan berlangsung dari tanggapan umum ke tanggapan spesifik terhadap berbagai rangsangan yang diterima.

c. Perkembangan terjadi secara berkesinambungan.

d. Berbagai bidang perkembangan berlangsung dengan kecepatan yang berbeda.

e. Terdapat berbagai keterkaitan dalam perkembangan.

Perbedaan individu dalam setiap perkembangan beberapa aspek tertentu karena adanya pengaruh bawaan terhadap kondisi lingkungan. Dengan kata lain, terdapat bukti bahwa faktor lingkungan lebih berpengaruh dalam menimbulkan perbedaan daripada faktor keturunan. Ini berlaku pada perkembangan fisik ataupun psikologis. Guru harus memahami perbedaan perkembangan pada anak usia dini karena setiap anak tidak berperilaku sama dan cara memperlakukan antara anak yang satu dan lainnya pun berbeda.

Periodisasi pola perkembangan yang disebut dengan periode pralahir, masa neonates, masa bayi, masa kanak-kanak awal, masa kanak-kanak akhir, dan masa puber. Pada semua periode ini terdapat keseimbangan dan ketidakseimbangan. Selain itu, ada perilaku yang normal dan ada perilaku yang bermasalah. Pada anak prasekolah, keseimbangan terjadi pada usia 4, 5, dan 6 tahun, sedangkan masa ketidakseimbangan terjadi pada usia 4,5, 5,5, dan 6,5 tahun.

Ada harapan sosial untuk setiap periode perkembangan harapan sosial ini berbentuk tugas perkembangan yang memungkinkan orang tua dan guru mengetahui usia anak yang mampu menguasai berbagai pola tertentu yang diperlukan bagi penyesuaian yang baik. Tugas perkembangan harus diperoleh anak. Jika tidak, anak akan merasa rendah diri dan tidak bahagia sehingga timbul ketidaksetujuan dan penolakan sosial, serta akan menyulitkan penguasaan tugas.

Setiap bidang perkembangan memiliki risiko tertentu, baik fisik maupun psikologis, yang dapat mengubah pola perkembangan. Beberapa pengaruh positif dan negatif datang dari sekitar lingkungan, serta sebagain lagi datang dari dalam diri anak. Apabilah hal ini terjdai, anak akan mengalami masalah penyesuaian yang bermasalah atau anak tersebut tidak matang.

Kebahagiaan bervariasi pada berbagai periode perkembangan. Tahun pertama kehidupan biasa merupakan saat yang paling bahagia, sedangkan masa 
Al-Ishlah: Jurnal Pendidikan - ISSN: 2087-949o (p); 2597-940X (e)

Vol. 11, No. 1 (2019)

remaja biasanya masa yang paling berpotensi bermasalah. Kebahagiaan memengaruhi penyesuaian masa kanak-kanak dan dalam batasan-batasan tertentu dapat dikendalikan.

Pada anak usia 5 tahun, seorang anak memiliki karakteristik antara lain sebagai berikut.

1. Berkaitan dengan perkembangan fisik, anak sangat aktif melakukan berbagai kegiatan. Hal itu bermanfaat untuk pengembangan otot kecil maupun besar.

2. Perkembangan bahasa juga semakin baik. Anak sudah mampu memahami pembicaraan orang lain dan mampu mengungkapkan pikirannya dalam batasbatas tertentu.

3. Perkembangan kognitif (daya pikir) sangat pesat, ditunjukkan dengan rasa ingin tahu anak yang luar biasa terhadap lingkungan sekitar. Hal itu terlihat dari seringnya anak menanyakan segala sesuatu yang dilihat.

4. Bentuk permainan anak masih bersifat individu, bukan permaianan sosial. Walaupun aktivitas bermain dilakukan secara bersama.

\section{METODE PENELITIAN}

Penelitian ini dilakukan melalui pendekatan kuantitatif dengan korelasi product moment. Adapun alat (instrumen) yang digunakan adalah angket, yaitu sejumlah pertanyaan yang diberikan kepada responden berkenaan dengan permasalahan penelitian (Sugiono, 2013: 317). Angket di dalam penelitian ini digunakan untuk mengetahui bagaimana pengaruh gadget dalam pola asuh orang tua terhadap anak usia dini. Wawancara yaitu pertemuan dua orang untuk bertukar informasi dan ide melalui tanya jawab, sehingga dapat dikonstruksikan makna suatu topik tertentu. Wawancara dilakukan dengan sejumlah orang tua dan guru di TKIT Ibu Harapan KecAmatan Bengkalis. Dokumentasi merupakan catatan peristiwa yang sudah berlalu. Dokumen bisa berbentuk tulisan, gambar, atau karya monumental dari seseorang (Sugiono, 2013: 317). Melalui dokumentasi, data diperoleh dari dokumen sekolah di TKIT Ibu Harapan Kecamatan Bengkalis. Analisis data dilakukan dengan pendekatan kuantitatif, yaitu korelasi produk moment yang pengolaham datanya melalui aplikasi SPSS 22.0. Kemudian data kuantitatif dinarasikan dengan pendekatan kualitatif dengan tujuan untuk memperoleh makna hubungan antar variabel yang sedang diteliti sehingga dapat digunakan untuk menjawab rumusan masalah dalam penelitian. 
Al-Ishlah: Jurnal Pendidikan - ISSN: 2087-949o (p); 2597-940X (e)

Vol. 11, No. 1 (2019)

\section{HASIL DAN PEMBAHASAN}

Analisis hasil penelitian yang telah penulis lakukan dapat dilihat seperti pada tabel seperti berikut.

Tabel 1. Analisis Data Gadget dan Pola Asuh

\begin{tabular}{|c|c|c|c|c|c|}
\hline No & $\begin{array}{c}\text { Keterangan } \\
\text { Angket }\end{array}$ & Total & Rata-Rata & Hasil & Persentase \\
\hline 1 & Gadget & 2166 & 3 & 70,82 & 29,18 \\
\hline 2 & Pola Asuh & 5258 & 3 & 70,82 & 29,18 \\
\hline \multicolumn{4}{|c|}{ TOTAL } & $\mathbf{7 4 2 4}$ & \multicolumn{3}{l|}{} \\
\hline
\end{tabular}

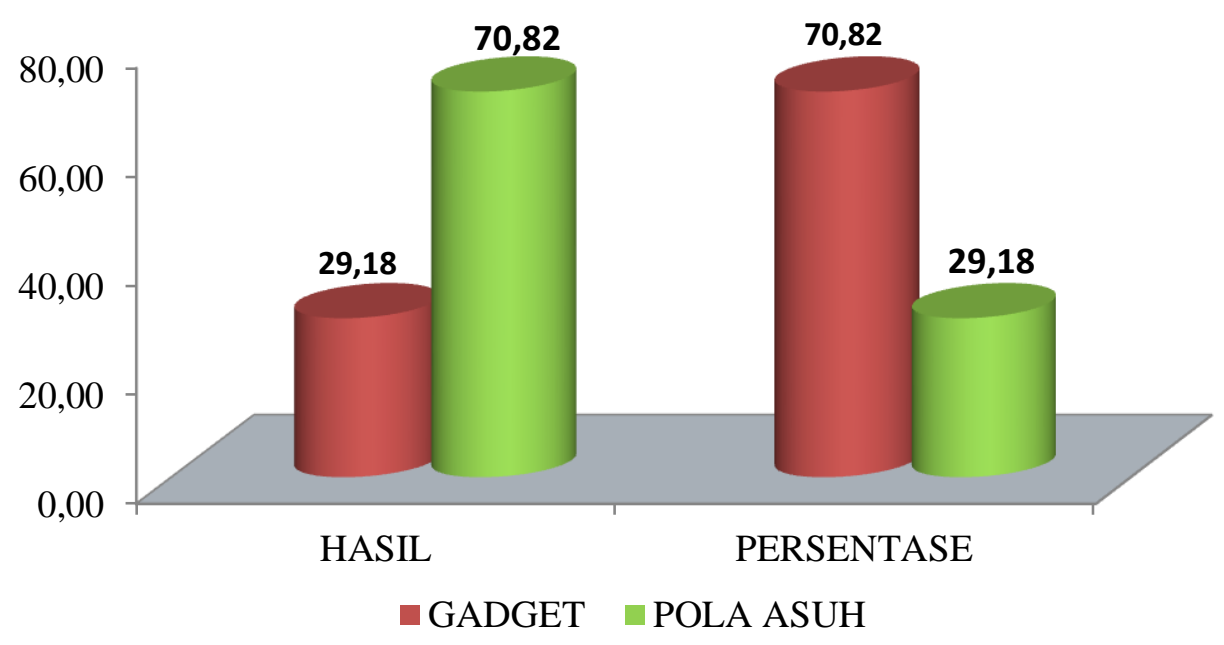

Gambar 2. Grafik Analisa Data 
Al-Ishlah: Jurnal Pendidikan - ISSN: 2087-949o (p); 2597-940X (e)

Vol. 11, No. 1 (2019)

Tabel 3. Korelasi

\begin{tabular}{|cl|l|l|}
\hline & & Gedget & Pola Asuh \\
\hline Gedget & Pearson & 1 & -.060 \\
& Correlation & & \\
& Sig. (2-tailed) & & .733 \\
N & 35 & 35 \\
\hline Pola Asuh & Pearson & 060 & 1 \\
& Correlation & & \\
& Sig. (2-tailed) & .733 & \\
& N & 35 & 35 \\
\hline
\end{tabular}

\section{Analisis Hasil Korelasi}

Setelah disebarkan angket untuk menemukan jawaban orang tua yang memiliki gawai dari 35 orang sebanyak 70,82\% yaitu lebih kurang 25 orang, sedangkan yang tidak memiliki gawai $29,18 \%$, yaitu lebih kurang 10 orang. Kemudian, ada pengaruh yang signifikan dibuktikan dengan nilai 0,733, bahwa pola asuh dipengaruhi oleh gawai dengan hasil data $70,82 \%$, pada rentang pengaruh yang kuat, dengan dibuktikan nilai korelasi 0,60 setelah analisisdianalisis dengan korelasi product moment.

Tabel 4. Analisis Data Pola Asuh

\begin{tabular}{|c|c|c|c|}
\hline No & Pola Asuh & Hasil & Persentase \\
\hline 1 & $\begin{array}{c}\text { Permisive Parenting (Polah } \\
\text { Asuh Permisif) }\end{array}$ & 11,69 & 88,31 \\
\hline 2 & $\begin{array}{c}\text { Authoritative Parenting } \\
\text { (Pola Asuh Demokratis) }\end{array}$ & 38,35 & 61,65 \\
\hline 3 & $\begin{array}{c}\text { Authoriarian Parenting } \\
\text { (Pola Asuh Otoriter) }\end{array}$ & 49,96 & 50,04 \\
\hline
\end{tabular}


Al-Ishlah: Jurnal Pendidikan - ISSN: 2087-949o (p); 2597-940X (e)

Vol. 11, No. 1 (2019)

Dari 56 item pernyataan angket yang telah disebarkan dan diisi oleh 35 orang tua dari anak usia dini (5 tahun), ada 13 pernyataan $(11,69 \%$ ) yang menyatakan tidak setuju, 26 pernyataan $(38,5 \%)$ yang menyatakan setuju, dan 41 yang menyatakan setuju $(49,96 \%)$. Berarti yang menyatakan setuju bahwa pola asuh dipengaruhi oleh gawai adalah orang tua yang menerapkan polah asuh permisif, yaitu $88,31 \%$. Yang menyatakan tidak setuju adalah orang tua yang menerapkan pola asuh demokratis $61,65 \%$ dengan catatan kalau anak menggunakan gawai tetap didampingi orang tua dan diberi batasan, terutama untuk menambah wawasan. Kemudian, pola asuh otoriter 50,04\% dan melarang keras bahkan disertai dengan marah kepada anak yang menggunakan gawai.

Dalam penyajian hasil analisis data ini terlihat juga dalam bentuk grafik seperti pada gambar 2 .

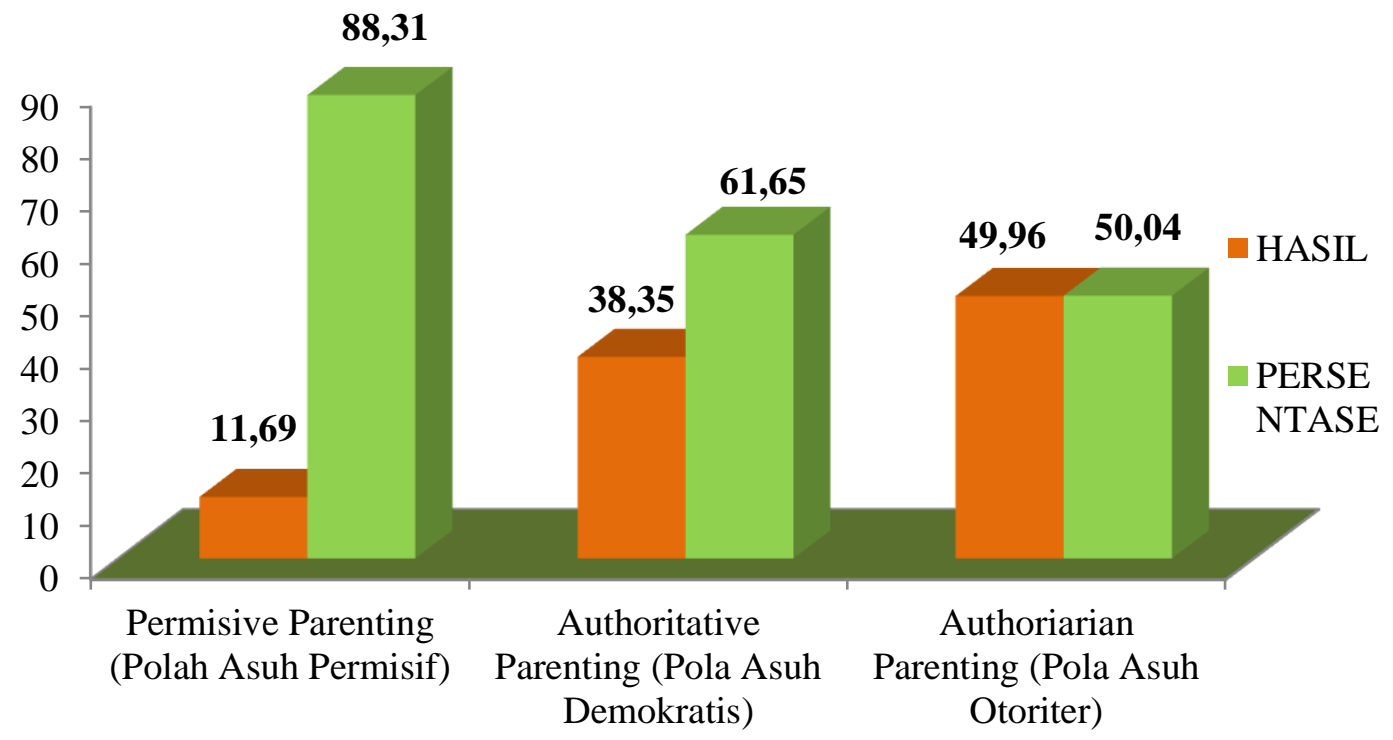

\section{Gambar 5. Analisis Data}

Faktor yang menghambat maupun mendukung pola asuh orang tua terhadap anak usia dini

1. Faktor penghambat dalam pengasuhan orang tua terhadap anak 5 tahun yaitu

a. Maraknya anak-anak usia dini (2-6) tahun yang sudah menggunakan gawai.

b. Anak-anak usia 5 tahun sudah mulai bisa berteman dan memilih teman.

c. Sebagian anak usia 5 tahun sudah mulai mempunyai keinginanan sendiri.

d. Sebagian anak-anak usia 5 tahun sudah sulit diatur.

e. Merebaknya teknologi. 
Al-Ishlah: Jurnal Pendidikan - ISSN: 2087-9490 (p); 2597-940X (e)

Vol. 11, No. 1 (2019)

f. Maraknya game pada aplikasi gawai sehingga anak kecanduan untuk bermain gawai.

g. Tidak tersedia paket belajar yang lengkap pada aplikasi gawai untuk menambah pengetahuan. anak, seperti tidak ada aplikasi untuk belajar agama, tidak ada aplikasi paket belajar untuk anak.

h. Tidak ada kerja sama yang baik antara guru dan orang tua dalam pola pengasuhan anak.

i. Orang tua tidak mengetahui cara blcking site pada gadget seperti blocking site untuk Youtube.

2. Faktor pendukung dalam pengasuhan orang tua yaitu sebaga berikut.

1. Adanya kerja sama yang baik dalam keluarga (antara ayah, ibu, dan anak).

2. Adanya komitmen yang sama antara keluarga.

3. Adanya konsistensi dalam pengasuhan.

4. Orang tua menyediakan alat permainan edukatif bagi anak sesuai dengan usianya.

5. Orang tua menyediakan aplikasi permainan edukasi pada gawai untuk anak usia 1-5 tahun, seperti: aplikasi belajar berhitung, mengenal warna/mewarnai, belajar membaca, belajar menulis, belajar menggambar, belajar bahasa Inggris, belajar bahasa Arab, aplikasi aku balita cerdas, puzzle, marbel belajar flora dan fauna.

6. Orang tua juga menyediakan aplikasi pada gawai untuk belajar mengaji/marbel learn Alquran, marbel salat, edukasi anak muslim, lagu islami yang indah, marbel belajar hijaiyah + suara, kumpulan doa anak muslim, belajar iqro dengan audio, kuis agama Islam, belajar membaca Alquran, doa, zikir, dan azan merdu.

7. Tersedianya paket belajar yang lengkap pada aplikasi gawai seperti: paket belajar lengkap TK dan PAUD, Riri dongeng, cerita dan buku anak + audio, marbel belajar budaya nusantara, video lagu anak, dan lain-lain.

8. Adanya kerja sama antara guru dan orang tua dalam pengasuhan anak.

9. Orang tua mengetahui cara blocking site pada gawai terutama blocking site di Youtube.

3. Analisis terhadap orang tua dan anak yang dipengaruhi gawai

1) Bagi orang tua sebaiknya melakukan kegiatan-kegiatan yang terprogram sehingga bisa meminimalisasi penggunaan gawai, seperti

- menyiapkan makanan buat keluarga

- mengantar dan menjemput anak sekolah

- mendampingi anak pada saat belajar

- mengantarkan dengan dongeng ketika anak pada saat mau tidur 
Al-Ishlah: Jurnal Pendidikan - ISSN: 2087-949o (p); 2597-940X (e)

Vol. 11, No. 1 (2019)

- mengenalkan buku-buku cerita, pada saat liburan membawa anak ke toko buku dan toko mainan yang sesuai dengan usianya.

2) Bagi anak

- mengenalkan program-program samart edu dalam gawai

- membatasi anak dalam penggunaan gawai

- mendukung kemauan anak dalam kegiatan ekstrakurikuler, seperti berenang, memancing, bermain layang-layang, ke kebun binatang.

- anak didampingi dan diarahkan bermain puzzle

- Bersama-sama seluruh keluarga berkomitmen untuk melakukan suatu kegiatan yang positif, seperti: magrib mengaji, tamasya bersama, memasak kesukaan, dan lain-lain yang bermanfaat bagi seluruh keluarga.

3) Bagi lembaga pendidikan anak usia dini

Membuat dan menyediakan program parenting

\section{SIMPULAN}

Berdasarkan hasil pengolahan data yang telah dikumpulkan, kemudian dikaji, dianalisis, dan dibahas secara mendalam, dapat disimpulkan sebagai berikut. Pertama, ada pengaruh yang signifikan pada penggunaan gawai dalam pengasuhan orang tua terhadap anak usia 5 tahun, yaitu untuk pola asuh permisif $88,31 \%$ orang tua dipengaruhi oleh gawai dalam pengasuhannya dan membiarkan anak menggunakan gadget walau tanpa pendampingan dan pembatasan. Kemudian, orang tua yang menerapkan pola asuh demokratis $38,35 \%$, berarti orang tua yang menerapkan pola asuh demokratis setuju bahwa pengasuhannya dipengaruhi oleh gawai dan anak menggunakan gawai, tetapi untuk menambah wawasan dengan pendampingan dan menambah wawasan. Orang tua yang menerapkan pola asuh otoriter $49,96 \%$, berarti orang tua yang menerapkan pola asuh otoriter setuju bahwa pengasuhannya dipengaruhi oleh gawai, tetapi orang tua melarang keras anak-anaknya menggunakan gawai, bahkan orang tua marah apabila anak-anak menggunakan gawai tanpa memberikan penjelasan. Kedua, adapun faktor-faktor yang menghambat pengasuhan anak pada anak usia dini (usia 5 tahun) yaitu maraknya anak-anak usia dini (2-6 tahun) yang sudah menggunakan gawai; anak-anak usia 5 tahun sudah mulai bisa berteman dan memilih teman; sebagian anak usia 5 tahun sudah mulai mempunyai keinginan sendiri; sebagian anak-anak usia 5 tahun sudah sulit diatur; dan merebaknya teknologi. Ketiga, faktor pendukung dalam pengasuhan orang tua, yaitu: adanya kerja sama yang baik dalam keluarga (antara ayah, ibu, dan anak); adanya komitmen yang sama antara keluarga; adanya konsistensi dalam pengasuhan dan orang tua menyediakan alat permainan edukatif bagi anak sesuai dengan usianya 
Al-Ishlah: Jurnal Pendidikan - ISSN: 2087-949o (p); 2597-940X (e)

Vol. 11, No. 1 (2019)

seperti menyediakan aplikasi edukatif pada gawai untuk belajar, khusunya dalam pelajaran agama seperti belajar mengaji, salat, dan lainny,a sehingga gawai yang digunakan anak bisa bermanfaat untuk perkembangan kecerdasannya.

\section{DAFTAR PUSTAKA}

Alfiana, E. (2013). Pola Asuh Orang Tua Terhadap Anak. Jakarta.

Astuti, A. P., \& Nurmalita RPS, A. (2014). Teknologi Komunikasi dan Prilaku Remaja. Jurnal Analisis Sosiologi.

B. Hurlock, E. (1999). Psikologi Perkembangan Suatu Pendekatan Sepanjang Rentang Kehidupan. Jakarta: Erlangga.

Burhanudin. (2009). Pendidikan Psikologi Perkembangan Peserta Didik. Jogjakarta: R-Ruzz Media.

Creswell. (2010). Research Desain: Pendekatan Kualitatif, Kunatitatif, dan Mixed (Terjemahan). Yogyakarta: Pustaka Pelajar.

Desmita. (2012). Psikologi Perkembangan Peserta Didik. Bandung: Remaja Rosdakarya.

Faisal, N. (2016 ). Pola Asu Orang Tua Dalam Mendidik Anak Di Era Digital. AnNisa. Volume IX Nomor 2 Desember.

Furqon. (2011). Statistik Terapan untuk Penelitian. Bandung: Alfabeta.

Nizar, S. d. (2015). Pedoman Penulisan Skripsi. Bengkalis Riau: Islamic Culture Science And Technology.

Prof. Dr. Afrizal, M.A. (2015). Metode Penelitian Kualitatif: Sebuah Upaya Mendukung Penggunaan Penelitian Kualitatif Dalam Berbagai Disiplin Ilmu. Jakarta: RajaGrafindo Persada.

Rakhmawati. (2015). Peran Keluarga dalam Pengasuhan anak. Jurnal Bimbingan Konseling Islam, , I. Vol. 6, No. 1, Juni.

Ramayulis. (2004). Ilmu Pendidikan Islam. Jakarta: Kalam Mulia. 
Al-Ishlah: Jurnal Pendidikan - ISSN: 2087-949o (p); 2597-940X (e)

Vol. 11, No. 1 (2019)

Riduan. (2010). Dasar-dasar Statistik. Bandung: Alfabeta.

Shochib, M. (2014). Pola Asuh Orang Tua Dalam Membantu Anak Mengembangkan Disiplin Diri. Jakarta: Rineka Cipta.

Solihat, M. (2005). Komunikasi Orang Tua dan Pembentukan Kepribadian Anak. Mediator. Vol 6 No. 2 Desember.

Sugiono. (2013). Metode Penelitian Pendidikan. Bandung: Alfabeta.

Suharsimi, A. (2010). Prosedur Penelitian Suatu Pendekatan Praktik. Jakarta: PT. Rineka Cipta.

Sujarweni, V. (2014). Metodologi Penelitian. Yogyakarta: Pustaka Baru Press.

Syaifullah MS. (2006). Konsep Iptek Dan Keterpaduannya Dalam Alquran . Jurnal Hunafa. Vol. 3 No. 3, September.

Syamsu, Y. (2004). Psikologi Perkembangan Anak dan Remaja. Bandung: Remaja Rosdakarya.

Wibowo, A. (2017). Pendidikan Karakter Usia Dini (Strategi Membangun Karakter Di Usia Emas). Yogyakarta: Pustaka Pelajar.

Wiyani, N. A. (2016). Konsep Dasar Paud. Yogyakarta: Gava Media.

Yee-Jin Shin. (2014). Mendidik Anak Di Era Digital Cet. Bandung: PT Mizan Publik.

Yusuf, A. (2015). Metode Penelitian Kuantitatif, Kualitatif \& Penelitian Gabungan. Jakarta: Prenadamedia Group. 